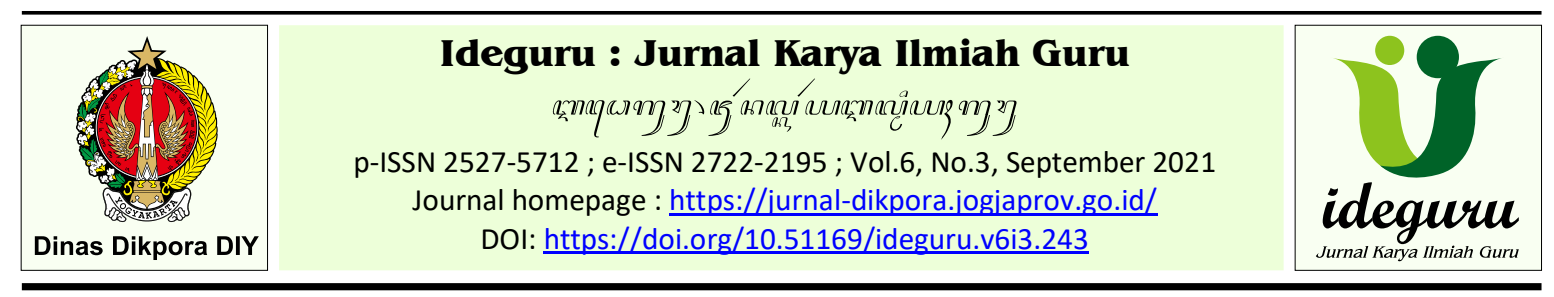

Artikel Penelitian - Naskah dikirim: 15/02/2021 - Selesai revisi: 01/08/2021 - Disetujui: 02/08/2021 - Diterbitkan: 01/09/2021

\title{
Pengembangan Orientasi Keterampilan Abad 21 pada Pembelajaran Fisika melalui Pembelajaran PjBL-STEAM Berbantuan Spectra-Plus
}

\author{
Sri Lestari \\ SMA Negeri 1 Yogyakarta, Yogyakarta, Daerah Istimewa Yogyakarta, Indonesia \\ bcl.fisika@gmail.com
}

\begin{abstract}
Abstrak: Penelitian ini bertujuan mendiskripsikan perkembangan ketrampilan abad 21 dengan pembelajaran PjBL berbasis STEAM berbantuan spectra-plus pada Materi Pokok gelombang bunyi prototype alat musik. Penelitian ini merupakan penelitian dan pengembangan (R \& D) dengan sampel siswa kelas XI MIPA 2 berjumlah 32 di SMA Negeri 1 Yogyakarta Semester 2 Tahun Pelajaran 2019/2020. Untuk mengetahui peningkatan kemampuan berpikir kritis ilmiah setelah pembelajaran PjBL berbasis STEAM berbantuan spectra-plus menggunakan normalized gain,sedangkan kemampuan keterampilan kreatif, komunikasi dan kolaborasi menggunakan angket dan lembar observasi. Metode yang digunakan one group pre-test post-test design. Hasil menunjukkan terdapat peningkatan kemampuan berpikir kritis ilmiah skor gain ternormalisasi 0,54 dan berpikir kreatif skor gain ternormalisasi 0,65 setelah diterapkan pembelajaran PjBL berbasis STEAM berbantuan spectra-plus pada kategori sedang. Dari lembar observasi untuk kemampuan kolaborasi pencapaian $73 \%$ dengan kategori tinggi dan kemampuan komunikasi 77\% dengan kategori tinggi. Tanggapan siswa terhadap penerapan pembelajaran sebesar 78,21\%. Respon siswa cukup positif terhadap penerapan PjBL berbasis STEAM dalam pembelajaran. Berdasarkan analisis data dan pembahasan disimpulkan pembelajaran metode STEAM dengan mengaitkan ilmu pengetahuan, teknologi, teknik, seni, dan matematika dapat mengembangkan kemampuan soft skills karena siswa diberikan pemahaman secara menyeluruh tentang keterkaitan bidang ilmu melalui pengalaman belajar keterampilan abad 21.
\end{abstract}

Kata kunci: PjBL; STEAM; keterampilan abad 21.

\section{Spectra-Plus Assisted STEAM Approach 21st Century Skills Orientation in Learning Physics}

\begin{abstract}
This study aims to describe the development of 21st century skills with spectra-plus-assisted STEAM-based PjBL learning on the main material of sound waves in musical instrument prototypes. This type of research is a type of research and development ( $R \& D)$ with a sample of 32 class XI MIPA 2 students in SMA Negeri 1 Yogyakarta Semester 2 of the 2019/2020 academic year. To determine the increase in scientific critical thinking skills after spectra-plus-assisted STEAM-based PjBL learning using normalized gain. Meanwhile, to determine the ability of creative skills, communication and collaboration using questionnaires and observation sheets.The results showed that there was an increase in scientific critical thinking skills, normalized gain score of 0.54 and creative thinking, normalized gain score of 0.65 after implementing PjBL learning based on spectra-plus assisted STEAM in the moderate category. From the results of the observation sheet, the average collaboration ability is $73 \%$ in the high category and the average communication ability is 77\% with the high category. The response of students to the application of STEM-based PjBL was 78.21\%. Student responses were quite positive towards the application of STEAMbased PjBL in learning. From the results of data processing and discussion, it can be concluded that learning with the STEAM method (Science, Technology, Engineering, Art and Mathematic) by linking science (science), technology, engineering, art, and mathematics can develop soft skills because students are given comprehensive understanding of the interconnectedness of disciplines through 21st century skills learning experiences.
\end{abstract}

Keywords: PjBL; STEAM; 21st century skills. 


\section{Pendahuluan}

Sesuai dengan konsep abad 21, ilmu pengetahuan dan teknologi mempunyai peran penting dalam kemajuan bangsa. Kecakapan utama dalam kehidupan di abad 21 meliputi sikap dan ketrampilan berpikir kritis, kreatif, kolaboratif, dan komunikatif. Pembelajaran yang dilaksanakan di sekolah harus melatih siswa siap menghadapi kehidupan di masa depan.

Model pembelajaran abad 21 yang mengembangkan soft skills peserta didik adalah pembelajaran model STEAM (Sains, Technology, Engineering, Art and Mathematic) pada pembelajaran ini mengaitkan ilmu pengetahuan (sains), teknologi, teknik, seni, dan matematika, sehingga peserta didik dibekali dengan pemahaman menyeluruh tentang keterkaitan antar bidang ilmu dan pengetahuan melalui pengalaman pembelajaran keterampilan abad 21. Model pembelajaran dengan menggunakan pendekatan STEAM merupakan pembelajaran kontekstual (Yakman, 2012), dimana peserta didik diajak untuk mempelajari dan memahami fenomena-fenomena di lingkungan sekitar dan dalam kehidupan sehari-hari.

Pembelajaran STEAM dapat mendorong peserta didik untuk mengeksplorasi kemampuan yang ada, dengan cara mereka sendiri. Pembelajaran STEAM juga dapat memunculkan karya berbeda dan tidak terduga dari masingmasing individu atau kelompoknya. Selain itu kemampuan dalam kolaborasi, kerjasama dan komunikasi dapat dimunculkan dalam proses pembelajaran karena pendekatan ini dilakukan berkelompok.

Pendekatan STEAM menjadikan peserta didik terlibat ambil bagian pada pembelajaran yang berlangsung dan akan memunculkan solusi dari permasalahan yang ada. Pembelajaran STEAM melatih peserta didik untuk mampu berpikir dalam mencari solusi dari permasalahan yang ada dengan mengkreasikan ide-idenya ke dalam teknologi terkini. Pembelajaran STEAM dapat menjembatani antara konsep yang masih abstrak secara matematis ke dalam ilmu pengetahuan, teknologi, tehknik dan seni. Dalam pembelajaran STEAM mengintegrasikan seni (art) untuk menumbuhkan dan memupuk kreativitas peserta didik dalam menciptakan suatu alat pembelajaran yang menyenangkan.

Berdasarkan kurikulum 2013, kompetensi dasar pada mata pelajaran Fisika adalah peserta didik mampu mengambil keputusan untuk menyelesaikan masalah dalam kehidupan seharihari dengan melibatkan peran Fisika sebagai dampak teknologi di masa depan, melalui proses ilmiah. Sehingga diperlukan pembelajaran yang dapat membangun pola pikir siswa untuk mencari penyelesaian pada setiap masalah dengan proses ilmiah. Kemampuan peserta didik dalam pemecahan masalah merupakan kemampuan dalam berpikir kritis dan kreatif untuk memecahkan permasalahan yang ada. Dengan demikian, Keterampilan peserta didik dalam proses berpikir secara kritis, inovatif dan kreatif harus dimunculkan, sehingga diharapkan mempunyai kompetensi ketrampilan abad 21.

Model pembelajaran sains yang bisa membangun ketrampilan abad 21 pada peserta didik sesuai dengan kurikulum 2013 adalah berbasis proyek. Pembelajaran ini berpusat pada peserta didik yang dalam pelaksanaanya akan memberikan pengalaman bermakna selama pembelajaran. Pembelajaran berbasis proyek dibangun berdasarkan pengalaman, konsep dan produk yang dihasilkan selama pembelajaran. Sistem pembelajaran berbasis proyek mengintegrasikan interdisipliner dari berbagai ketrampilan yang berbeda, misal ketrampilan dalam mengitepretasikan matematika, teknologi dalam membangun pemahaman konsep melalui integrasi pada pelajaran lain (Capraro, Morgan, \& Slough, 2013, p. 52).

Pembelajaran dengan pendekatan STEAM model PjBL pembuatan prototype alat musik seruling mengembangkan kemampuan berpikir kritis, berpikir kreatif, kemampuan komunikatif dan kolaboratif sesuai dengan keterampilan abad 21. Gambaran kemampuan berpikir kritis, kemampuan berpikir kreatif, berkomunikasi dan berkolaboratif yang diharapkan dalam pembelajaran ini sebagai berikut: (1) Berpikir kreatif yaitu menggabungkan aspek kreatifitas dan sains. Berpikir kreatif dalam pembelajaran ini siswa difokuskan untuk memahami interkoneksi antara konsep resonansi, pipa organa dan dawai pada gelombang bunyi dalam penyelesaian masalah pada saat membuat rancangan dan dalam melakukan uji coba prototype alat musik seruling dengan berbantuan spectra-plus. (2) Kemampuan berpikir kritis yang diharapkan adalah kemampuan peserta didik dalam merancang prosedur dan set alat musik, menyampaikan gagasan kreatif baik secara konsep maupun praktik dalam membuat prosedur dan rancangan alat musik berbahan alat bekas. (3) Komunikatif merupakan kemampuan siswa dalam menyampaikan ide gagasan, saat pelaksanaan diskusi tentang resonansi pada pipa organa dan dawai, ujicoba, mencari solusi pada setiap permasalahan dan memaparkan hasil uji coba rancangan alat. (4) Kolaborasi merupakan kemampuan siswa dalam melakukan kerjasama dalam kelompok pada saat mendiskusikan 
konsep gelombang bunyi berbantuan spectraplus.

Tujuan penelitian ini untuk memaparkan penerapan pembelajaran dengan pendekatan STEAM berbantuan spectra-plus sebagai salah satu model pembelajaran yang dapat membangun ketrampilan abad 21 pada siswa. Pembelajaran dengan pendekatan STEAM berbantuan spectra-plus Fisika dapat melatih kreativitas dan soft skills peserta didik, sesuai ketrampilan abad 21.

\section{Metode Penelitian}

Penelitian ini adalah jenis penelitian pengembangan (R\&D) yang dikembangkan Borg and Gall (1989) dalam Hanafi (2007) model RND terdiri dari empat ciri utama, diantaranya: 1) Studying Research Findings partinent to the product to be develop, 2) Developing the product base on this findings, 3) Field testing in the setting where it will be used eventually, 4) Revising it to correct the deficiencies found in the field-testing stage".

Pendekatan STEAM berbantuan spectra-plus ini merupakan pengembangan dari model PJBL yang sudah ada. Jadi tidak menciptakan pendekatan pembelajaran yang benar-benar baru.

Project Based Learning (PjBL) merupakan proses pembelajaran berbasis proyek yang berpusat pada peserta didik untuk memecahkan masalah, merancang dan membuat suatu karya (Ismayani, 2016). Spiko et al. (2017) menyatakan bahwa Science Technology Engineering Art Mathematic (STEAM) menawarkan kegiatan yang melibatkan siswa dalam tugas desain dan teknik untuk mengeksplorasi keterampilan sains dan matematik siswa melalui kreativitas, ekspresi dan aspek visual yang juga mendukung pemikiran logis dan materitik.

Model Pembelajaran Project Based Learning (PjBL)-STEAM merupakan proses pembelajaran dengan memadukan model pembelajaran berbasis proyek menggunakan pendekatan Science, Technology, Engineering, Art dan Mathematic (STEAM). Model PjBL-STEAM mendorong siswa untuk memperoleh pengetahuan lebih dalam melalui eksplorasi aktif dari tantangan dunia nyata dan masalah dengan mengintegrasikan setiap komponen STEAM (Annisa et al., 2019).

Penelitian ini mengimplementasikan PjBLSTEAM yang merupakan model pembelajaran kreatif dalam menyelesaikan masalah dengan memuat konten Science, technology, engineering, art and mathematic (STEAM). Tahapan pembelajaran model PjBL-STEAM pada penelitian ini dapat dilihat pada tabel 1 di bawah ini.

Tabel 1. Tahapan pembelajaran model PjBL-STEAM

\section{Langkah PjBL Langkah PjBL-STEAM}

Start with Start with essential question : essential pada tahap ini siswa diberikan question permasalahan yang terkait dengan materi yang akan dipelajari dengan memuat konten science.

Design Project Design Project : pada tahap ini siswa merancang sebuah proyek dengan mengandung unsur STEAM

Create schedule

Monitoring the students and progress of projects

Create schedule : pada tahap ini siswa bersama guru membuat kesepakatan jadwal pembuatan proyek hinga penyelesaian proyek.

Monitoring the studentsand progress of projects : pada tahap ini guru memonitor kegiatan pembuatan proyek dengan memperhatikan unsur STEAM.

Asses the outcomes and evaluation the experience

Asses the outcomes and evaluation the experience: Kegiatan akhir dilakukan dengan presentasi proyek, penilaian dan evaluasi. Guru menilai proyek yang dibuat siswa dengan melihat unsur STEAM.

Penelitian pengembangan Pembelajaran PjBL berbasis STEAM ini dilaksanakan di SMA Negeri 1 Yogyakarta pada kelas XI MIPA 2 mata pelajaran Fisika, semester genap Tahun Pelajaran 2019/2020 yang terdiri dari 32 peserta didik. Rentang waktu pelaksanaan penelitian antara bulan Januari sampai dengan Februari 2020.

Prosedur pembelajaran pada penelitian menggunakan 3 (tiga) langkah yaitu perencanaan, pelaksanaan dan tahapan akhir. Pada tahap awal perencanaan dengan membuat Skenario Pada Pelaksanaan Pembelajaran dan Lembar Kerja Peserta Didik (LKPD) PjBL STEAM, soal evaluasi. Pada pelaksanaan pembelajaran diberi perlakuan pembelajaran model PjBL berbasis STEAM. Tahapan terakhir dilaksanakan pengolahan data, pembahasan dan membuat kesimpulan.

Instrumen yang digunakan berupa soal dalam bentuk essai untuk mengukur 
keterampilan peserta didik dalam berpikir kritis inovatif dan berpikir kreatif peserta didik sebelum dan setelah pelaksanaan pembelajaran dengan pendekatan STEAM, kemampuan komunikasi dan kolaborasi siswa pada saat pembelajaran dapat diukur dengan menggunakan lembar observasi pembelajaran. Instrumen penelitian di validasi oleh dua guru Fisika SMA Negeri 1 Yogyakarta. Dari hasil validasi diperoleh bahwa instrumen valid untuk digunakan untuk penelitian.

Pada proses pengolahan data dengan memberikan skor pada soal essai disetiap indicator kemampuan kreatif ilmiah dan kritis ilmiah yang dimiliki siswa. Skor kemampuan peserta didik dalam berpikir kreatif mengacu pada rubrik instrumen test yang ditulis oleh $\mathrm{Hu}$ dan Adey (2002)

Pada kemampuan kritis ilmiah skor mengacu pada rubrik kriteria ACTA (Assesmen of Critical Thingking Ability). Peningkatan kemampuan keterampilan berpikir kritis ilmiah dan ketrampilan berpikir kreatif dapat diperoleh dengan mengunakan normalized gain pada skor rata-rata nilai pre-test dan nilai rata-rata post-test peserta didik. Nilai normalized gain dihitung dengan menggunakan persamaan (1) gain normal $<$ g $>$ sebagai berikut:

$N-\operatorname{Gain}(N)=\frac{\text { Nilai Posttest }- \text { Nilai Pretest }}{\text { Nilai Maksimal }- \text { Nilai Pretest }}$

\section{Hasil dan Pembahasan}

Pembelajaran berbasis proyek dapat menargetkan satu atau lebih suatu konten, namun STEAM dapat menjadi peluang besar untuk membuat proyek yang memenuhi unsur sains, matematika, teknologi dan bahkan unsur seni (Miller, 2017).

Penelitian yang dilakukan oleh Fatimah (2017), membuktikan bahwa penerapan pendekatan STEAM dalam pembelajaran menggunakan PjBL dapat mengembangkan keterampilan abad 21 yaitu berpikir kritis dan memecahkan masalah, kreatif dan inovatif, komunikasi dan kolaborasi, literasi informasi, literasi media, literasi teknologi, fleksibilitas dan adaptabilitas.

Menurut Reza (2017), Pendekatan STEAM dengan menggunakan project based learning dapat mengembangkan soft skills peserta didik yaitu bekerja sama, empati komunikasi, berpikir kritis, peduli lingkungan, kerja keras, keterampilan beradaptasi, tanggung jawab, berpikir kreatif, kepemimpinan, rasa ingin tahu dan jujur.
Tabel 2. Rubrik Pemberian Skor Pada Penilaian Ketrampilan berpikir Kreatif Ilmiah.

\begin{tabular}{|c|c|c|}
\hline No & Aspek KBK & Pedoman Penilaian \\
\hline 1. & $\begin{array}{l}\text { Fluency } \\
\text { (Kelancaran) }\end{array}$ & $\begin{array}{l}\text { jawaban siswa } \\
\text { dijumlahkan, dengan skor } \\
1 \text {. }\end{array}$ \\
\hline 2. & $\begin{array}{l}\text { Flexibility } \\
\text { (Keluwesan) }\end{array}$ & $\begin{array}{l}\text { dengan menjumlahkan } \\
\text { jawaban dari siswa dari } \\
\text { sudut pandang berbeda, } \\
\text { dengan skor } 1 \text {. }\end{array}$ \\
\hline 3. & $\begin{array}{l}\text { Originality } \\
\text { (Orisinalitas) }\end{array}$ & $\begin{array}{l}\text { jika jawaban siswa sama } \\
\text { dengan } 5 \% \text { siswa di kelas } \\
\text { diberi skor } 3 \text {, diberi skor } 2 \\
\text { jika } 5 \%-10 \% \text { jawaban } \\
\text { siswa sama dengan } \\
\text { jawaban siswa dikelas, } \\
\text { dan tidak menjawab maka } \\
\text { akan diberi skor } 0 .\end{array}$ \\
\hline 4. & $\begin{array}{l}\text { Fluency- } \\
\text { Science } \\
\text { Knowledge }\end{array}$ & $\begin{array}{l}\text { jika siswa tidak menjawab } \\
\text { maka diberikan skor 0, } \\
\text { jika siswa bisa } \\
\text { memaparkan desain yang } \\
\text { dibuat tetapi tidak dapat } \\
\text { menghubungkan dengan } \\
\text { konsep maka di beri skor } \\
1 \text { atau tidak menjawab } \\
\text { sama sekali diberi skor } 0 .\end{array}$ \\
\hline
\end{tabular}

Menurut Desta (2017), STEAM dapat mengembangkan kemampuan berpikir kreatif siswa dengan mengikuti keenam tahapan project based learning yaitu; (1) Penentuan pertanyaan mendasar (start with essential question), (2) Menyusun perencanaan proyek (design project), (3) Menyusun jadwal (create schedule), (4) Memantau siswa dan kemajuan proyek (monitoring the students and progress of projects), (5) Penilaian hasil (Assess the outcomes) dan (6) Evaluasi Pengalaman (evaluation the experience). Hasil penelitian lain mengungkapkan bahwa PjBL dapat dilakukan dengan tujuah tahap yaitu; identifikasi masalah, eksplorasi, membentuk pengertian, menganalisis ide, membuat proyek, pengujian dan perbaikan, yang terakhir adalah komunikasi dan refleksi (Kristiani, 2017)

Hasil perhitungan nilai rata-rata dan normalized gain untuk keterampilan berpikir kritis ilmiah siswa terdapat pada tabel 3 berikut.

Tabel 3. Nilai keterampilan berpikir kritis

\begin{tabular}{crccc}
\hline $\begin{array}{c}\text { Pre- } \\
\text { Test }\end{array}$ & $\begin{array}{r}\text { Post- } \\
\text { Test }\end{array}$ & Gain & N-gain & Kategori \\
\hline 1,34 & 2,78 & 1,43 & 0,54 & sedang \\
\hline
\end{tabular}


Berdasarkan tabel 2, terlihat hasil tes ketrampilan berpikir kritis ilmiah memiliki rata-rata nilai pretest sebesar 1,34 dan rata-rata nilai post-test sebesar 2,78, hal ini menunjukkan ada peningkatan yang signifikan pada ketrampilan berpikir kreatif dengan skor gain 1,43 dan skor gain ternormalisasi sebesar 0,54 dengan kategori sedang. Kemampuan peserta didik dalam berpikir kritis ilmiah ini ditinjau dari aspek berpikir kreatif ilmiah dapat dilihat dalam pada tabel 4 .

Tabel 4. Peningkatan tiap aspek keterampilan berpikir kritis ilmiah

\begin{tabular}{lccccc}
\hline Aspek & $\begin{array}{c}\text { Pre } \\
\text { Test }\end{array}$ & $\begin{array}{c}\text { Post- } \\
\text { Test }\end{array}$ & Gain & $\begin{array}{c}\mathrm{N}- \\
\text { gain }\end{array}$ & Kategori \\
\hline $\begin{array}{l}\text { Critical } \\
\text { ability }\end{array}$ & 1,46 & 3,18 & 1,71 & 0,68 & Sedang \\
$\begin{array}{l}1 \\
\text { Critical }\end{array}$ & & & & & \\
$\begin{array}{l}\text { ability } \\
2\end{array}$ & 1,28 & 2,56 & 1,28 & 0,47 & Sedang \\
$\begin{array}{l}\text { Critical } \\
\text { ability } \\
3\end{array}$ & 1,28 & 2,59 & 1,31 & 0,48 & Sedang \\
\hline
\end{tabular}

Dari hasil tes ketrampilan berpikir kritis di peroleh bahwa untuk indikator Critical ability 1 yang merupakan kemampuan siswa dalam mengkaitkan ilmu pengetahuan dalam kesimpulan terkait mengalami peningkatan sebesar 0,68 dengan kategori sedang. Dari hasil penelitian sebagian besar peserta didik telah mampu menjawab benar ,menganalisis data serta mampu menjelaskan tentang konsep materi yang di pelajari yaitu gelombang bunyi.

Aspek Critical ability 2 yaitu kemampuan siswa dalam merancang alat dengan mengintegrasikan menjadi pengetahuan baru, dari hasil pengolahan data terlihat penigkatan hasil pembelajaran untuk aspek ini dengan kategori sedang. Hal ini menggambarkan bahwa sebagaian besar siswa mampu memaparkan dan mendesaian studi kasus dengan menggunakan anologi dalam pembuktian pendapat mereka.

Dan pada bagian Critical ability yang merupakan kemampuan siswa dalam menginterpretasikan pengetahuan lain dari pengetahuan tertentu ada peningkatan sebesar 0,48 yang masuk kategori sedang setelah dilakukan pembelajaran. Hasil post-test menunjukkan nilai rata-rata 2,59 hal ini menunjukkan bahwa siswa mampu mengintegrasikan konsep dengan rancangan desain yang mereka buat tetapi belum bisa memperkirakan adanya kemungkinan interpretasi lain.

Data hasil test ketrampilan berpikir kreatif peserta didik dihitung nilai normalized gainnya. Nilai rata-rata dan normalized gain untuk kemampuan berpikir kreatif ilmiah siswa seperti pada tabel 5 berikut.

Tabel 5. Nilai keterampilan berpikir kreatif ilmiah

\begin{tabular}{ccccc}
\hline $\begin{array}{c}\text { Pre- } \\
\text { Test }\end{array}$ & $\begin{array}{c}\text { Post- } \\
\text { Test }\end{array}$ & Gain & N-gain & Kategori \\
\hline 4,04 & 7,25 & 3,20 & 0,65 & sedang \\
\hline
\end{tabular}

Berdasarkan tabel 5, jika diperhatikan terlihat hasil tes ketrampilan berpikir kreatif ilmiah memiliki rata-rata pre-test sebesar 4,04 dan nilai rata-rata post-test sebesar 7,25, hal ini menunjukkan ada peningkatan yang signifikan pada ketrampilan berpikir kreatif dengan skor gain 3,20 dan skor gain ternormalisasi sebesar 0,65 dengan kategori sedang.

Kemampuan peserta didik dalam berpikir kreatif ilmiah ini ditinjau dari aspek berpikir kreatif ilmiah dapat dilihat dalam pada Tabel .5. Perkembangan keterampilan berpikir kreatif ilmiah peserta didik aspek kelancaran memiliki skor nilai kenaikan paling signifikan dengan skor $\mathrm{N}$-Gain $(<\mathrm{g}>$ ) pada 0,89 dengan kategori tinggi. Tetapi di sisi lain, peningkatan terendah terjadi pada aspek Fluency-Science Knowledge $(0,40)$.

Hal ini tampak dari nilai post-test yang menunjukkan bahwa kemampuan siswa dalam menghubungkan desain yang mereka buat dengan konsep syarat materi yang dipelajari belum maksimal. Pada aspek Flexibility dan Originality keduanya mengalami peningkatan yang tidak maksimal hal ini dapat dilihat dari jawaban pre-test, banyak siswa yang membiarkan jawaban kosong.

Tabel 6. Peningkatan tiap aspek keterampilan berpikir kreatif ilmiah

\begin{tabular}{lccccc}
\hline \multicolumn{1}{c}{ Aspek } & Pre Test & Post Test & Gain & N-gain & Kategori \\
\hline Fluency (Kelancaran) & 1,25 & 1,93 & 0,68 & 0,89 & Tinggi \\
Flexibility (Keluwesan) & 1,13 & 2,13 & 1 & 0,53 & Sedang \\
Originality (Orisinalitas) & 0,78 & 1,50 & 0,72 & 0.59 & Sedang \\
Fluency-Science Knowledge & 0,84 & 1,71 & 0,87 & 0,40 & Sedang \\
\hline
\end{tabular}


Dari hasil pre-test yang diberikan, pada aspek originality jawaban siswa terkait gambar desain banyak yang sama dengan desain pada contoh yang diberikan, dan tidak memperhatikan bentuk serta ukuran. Setelah diterapkannya pembelajaran yang berbasis proyek, maka jawaban yang diberikan pada akhir test (posttest) sedah memenuhi kategori desain yang sesuai indikator, tetapi masih ditemukan beberapa detail desain yang belum sesuai.

Penilaian kemampuan siswa dalam berkomunikasi pada saat proses pembelajaran dapat diperoleh melalui lembar observasi. Hasil yang diperoleh pada kemampuan komunikasi pada kategori sedang dan pada kemampuan kolaborasi pada kategori sangat tinggi. Kemampuan peserta didik dalam berkomunikasi dapat dilihat dalam pada tabel 7.

Tabel 7. Kemampuan komunikasi siswa tiap aspek indikator komunikasi

\begin{tabular}{llcc}
\hline No & \multicolumn{1}{c}{ Indikator } & Persentase & Kategori \\
\hline $1 . \quad$ & $\begin{array}{l}\text { Mengemukakan } \\
\text { informasi dan } \\
\text { gagasan kepada } \\
\text { perseorangan } \\
\text { atau kelompok }\end{array}$ & $83 \%$ & $\begin{array}{l}\text { Sangat } \\
\text { Tinggi }\end{array}$ \\
2. & & \\
& $\begin{array}{l}\text { Memberikan } \\
\text { perhatian saat } \\
\text { orang lain } \\
\text { berbicara } \\
\text { Memberikan }\end{array}$ & $86,7 \%$ & Sangat \\
respon & $73,3 \%$ & Tinggi \\
B. & & Tinggi \\
B. & $66,7 \%$ & Tinggi \\
\hline
\end{tabular}

Pada saat pelaksanaan presentasi hasil proyek, seluruh siswa diwajibkan untuk berpartisipasi aktif dalam menyampaikan hasil proyek yang dibuat, sehingga indikator kemampuan siswa dalam berkomunikasi lisan dapat terukur. Dari hasil pengolahan data diperoleh bahwa kemampuan siswa dalam mengemukakan informasi telah memenuhi seluruh kreteria, sehingga dapat dikategorikan baik.

Pada saat pembelajaran, siswa diharapkan memberikan perhatian saat guru memaparkan atau pada saat siswa lain mempresentasikan materi. Sehingga proses komunikasi timbal balik atau dua arah terbentuk dan berjalan dengan baik hal ini ditunjukkan dengan pencapaian pada indikator ini mencapai angka $86,7 \%$.

Dalam berkomunikasi saling memberikan respon sangat penting. Respon yang diberikan dari kedua belah pihak menunjukkan adanya komunikasi aktif dan adanya umpan balik dari keduanya. Dalam komunikasi respon yang diberikan berpengaruh pada hasil komunikasi secara keseluruhan.

Pada saat presentasi hasil, di harapkan siswa dari kelompok lain memberika respon dan tanggapan, saran, kritikan, atau perbaikan. Pada kenyataannya berdasarkan hasil penelitian yang telah dilakukan, kemampuan memberikan respon siswa dikategorikan tinggi dengan angka 73,3\%. Pada aspek bertanya kemampuan siswa mencapai $66,7 \%$ dengan kategori tinggi. Siswa cukup antusias dalam memberikan pertanyaan kepada kelompok lain.

Kemampuan siswa dalam berkomunikasi secar lisan dapat dilihat bagaimana siswa tersebut memaparkan ide gagasan dan menyampaikan informasi, memberikan respond dan tanggapan pada saat orang lain berbicara atau menyampaikan pendapatnya. Dari hasil pengolahan data diperoleh bahwa kemampuan siswa kelas XI MIA 2 untuk aspek ketrampilan berkomunikasi mencapai presentase yang cukup tinggi yaitu $77 \%$. Sehingga dapat disimpulkan bahwa dengan pembelajaran berbasis proyek STEAM siswa dilatih untuk berkomunikasi, mulai dari berkomunikasi dalam kelompoknya hingga mengkomunikasikan hasil proyek mereka kepada siswa lainnya di depan kelas. Kemampuan siswa dalam berkolaborasi dapat dilihat pada tabel 8 .

Tabel 8. Kemampuan kolaborasi Siswa

\begin{tabular}{|c|c|c|c|}
\hline No & Indikator & Persentase & Kategori \\
\hline 1. & $\begin{array}{l}\text { Aktif bekerja } \\
\text { kelompok }\end{array}$ & $87 \%$ & $\begin{array}{l}\text { Sangat } \\
\text { Tinggi }\end{array}$ \\
\hline 2. & $\begin{array}{l}\text { Melaksanakan } \\
\text { tugas sesuai } \\
\text { kesepakatan }\end{array}$ & $73 \%$ & Tinggi \\
\hline 3. & $\begin{array}{l}\text { Membantu sesame } \\
\text { anggota kelompok }\end{array}$ & $70 \%$ & Tinggi \\
\hline 4. & $\begin{array}{l}\text { Rela berkorban } \\
\text { membantu orang } \\
\text { lain }\end{array}$ & $60 \%$ & Sedang \\
\hline
\end{tabular}

Kemampuan berkolaborasi siswa dapat dilihat dari bagaimana keterlibatan dalam kerja kelompok, kesediaan melakukan tugas dan membantu orang lain.Indikator pada kemampuan kolaborasi siswa saling berkaitan dalam memenuhi kriteria pada proses kolaborasi di dalam kelas. Dari hasil analisis diperoleh bahwa kemampuan siswa dalam berkolaborasi untuk siswa kelas XI Mipa 2 masuk dalam kategori tinggi dengan prosentase pada setiap indikator 73\%. Hal ini menunjukkan bahwa pembelajaran dengan pendekatan STEAM, dapat melatih kemampuan siswa dalam berkolaborasi baik dengan kelompoknya maupun dengan kelompok lain. Pembuatan sebuah produk 
merupakan hasil dari kolaborasi bersama. Sebagaimana telah tercantum dalam Trilling dan Fadel yang menyatakan ketrampilan siswa dalam berkolaborasi mengacu pada kemampuan siswadalam berkomunikasi dan berkolaborasi dengan anggota kelompok sendiri maupun kelompok lain (Trilling dan Fadel,2009)

\section{Nilai Kebaruan dalam Penelitian}

Pembelajaran Fisika dengan pendekatan STEAM berbantuan spectra-plus merupakan inovasi pembelajaran yang dapat mengembangkan keterampilan abad 21 pada siswa. Pada pembelajaran ini guru diharapkan mampu memfasilitasi siswa dalam mengembangkan kreativitas dan kemampuan mengintegrasikan konsep Science, Teachnology, Engineering, Art, and Mathematics dalam proses pembelajaran.

Dalam penerapan pendekatan STEAM berbasis aktivitas mampu membuat dimensi pengetahuan pada pembelajaran Fisika lebih bervariasi. Pembelajaran Fisika melalui pemberian proyek dengan pendekatan STEAM mampu mengasah siswa dalam membuat keputusan dalam mencari solusi permasalahan yang ada, mengembangkan keterampilan siswa menciptakan gagasan kreatif dan inovatif sesuai dengan perkembangan Ilmu pengetahuan dan teknologi. Pendekatan STEAM mampu mendorong siswa untuk memiliki kompetensi dasar dan keterampilan sesuai kebutuhan pada keterampilan abad-21, sehingga siswa akan mampu mencari solusi dari permasalahan yang muncul dalam diri dan sekitarnya.

\section{Simpulan dan Saran}

Dari pemaparan analisis data serta pembahasan maka dalam penelitian ini, dapat disimpulkan bahwa: Peningkatan ketrampilan abad 21 yang dicapai pada penerapan pembelajaran dengan pendekatan STEAM berbantuan spectra-plus pada materi gelombang bunyi. Pembelajaran dengan penerapan STEAM mengarahkan siswa berpikir kritis dalam mencari pemecahan masalah. Siswa mampu mengamati permasalahan yang ada, dengan membandingkan hasil pengamatan sehingga dapat mencari solusi dari permasalahan yang ada. Pada proses pembuatan produk dapat mendorong siswa untuk menggali kemampuan untuk memperoleh pengetahuan baru dari produk yang dihasilkan.

Dari hasil tes ketrampilan berpikir kritis ilmiah memiliki rata-rata pre-test sebesar 1,34 dan nilai rata-rata post-test sebesar 2,78 , hal ini menunjukkan ada peningkatan yang signifikan pada ketrampilan berpikir kreatif dengan skor gain 1,43 dan skor gain ternormalisasi sebesar 0,54 dengan kategori sedang.

Penerapan pendekatan STEAM pada pembelajaran dapat meningkatkan ketrampilan siswa dalam berpikir kreatif, dari hasil tes ketrampilan berpikir kreatif memiliki rata-rata pre-test sebesar 4,04 dan nilai rata-rata post-test sebesar, 7,25 hal ini menunjukkan ada peningkatan yang signifikan pada ketrampilan berpikir kreatif dengan skor gain 3,20 dan skor gain ternormalisasi sebesar 0,65 dengan kategori sedang. Kemampuan berpikir kreatif yang dimiliki oleh siswa akan membangun kreatifitas dalam mendesain suatu produk, memecahkan masalah dan mencari solusi terhadap permasalahan yang.

Pendekatan STEAM dapat mengarahkan siswa memiliki keterampilan komunikasi dan kolaborasi yang baik. Anggota kelompok saling bekerja sama menyelesaikan proyek yang diberikan. Dari hasil pengolahan data diperoleh rata rata pencapaian keterampilan komunikasi $77 \%$ pada kategori tinggi dan $73 \%$ pada rata-rata kemampuan kolaborasi dengan kategori tinggi.

Hal ini dapat disimpulkan bahwa pendekatan STEAM dapat mengarahkan siswa memiliki ketrampilan dalam berkolaborasi dan berkomunikasi dengan baik. Terjadi interaksi dan bekerja sama dalam menyelesaikan proyek yang harus diselesaikan. Dengan adanya pertukaran pengetahuan dan informasi pada saat diskusi menunjukkan terjadinya komunikasi dan kolaborasi yang baik. Dalam pembelajaran ini akan terbentuk hubungan yang kompak, siswa merasa semakin dekat dan akrab dengan teman yang sebelumnya tidak dekat.

Tujuan dari pemberian angket tentang pembelajaranSTEAM yaitu untuk menghimpun data tanggapan siswa serta saran dan masukan terhadap model pembelajaran tersebut, sehingga diperoleh kecenderuangan atau sikap siswa setelah pelaksanaan pembelajaran dilaksanakan. Angket skala sikap terdiri atas 15 butir pernyataan.Dari hasil angket tanggapan siswa terhadap pembelajaran STEAM diperoleh hasil $78,46 \%$ siswa merasa senang dan termotivasi belajar dengan PjBL berbasis STEAM; sebesar $76,85 \%$ siswa merasa bahwa dengan pembelajaran PjBL berbasis STEAM membantu siswa dalam memahami materi pembelajaran dan membentuk sikap kreatifitas; 80,48\% siswa merasa terbantu dalam kegiatan pembelajaran dan diskusi kelompok; $77,65 \%$ siswa tertarik untuk mengikuti kembali pembelajaran PjBL berbasis STEAM pada pembelajaran materi selanjutnya. Secara keseluruhan skor pada 
angket tanggapan siswa terhadap pembelajaran STEAM sebesar 78,21\% siswa. Dengan demikian dapat disimpulkan hampir seluruh siswa merasa tertarik dan senang dengan penerapan pembelajaran PjBL berbasis STEAM selama kegiatan pembelajaran.

Dalam pelaksanaan pembelajaran STEAM model PjBL di sesuaikan dengan karakteristik masing-masing mata pelajaran serta indikator pada masing-masing kompetensi dasar yang akan dicapai. Pembelajaran STEAM dapat diintegrasikan dengan metode pembelajaran lain.

\section{Daftar Pustaka}

Annisa, Rifka., M.H. Efendi., Damris. (2019). Peningkatan Kemampuan Berpikir Kreatif Siswa dengan Menggunakan Model Project Based Learning berbasis STEAM (Science, technology, engineering, arts, dan mathematics) pada Materi Asam dan Basa di SMA N 11 Kota Jambi. Journal of the Indonesian Society of Integrated Chemistry. 10(2), 14-22.

Capraro, R. yr., Capraro, M. M., Morgan, J. R., \& Slough, S. W. (2013). STEM Project Based Learning: An Integrated Science, Technology, Engineering, and Mathematics (STEM) Approach. STEM Project-Based Learning an Integrated Science, Technology, Engineering, and Mathematics (STEM) Approach. http://d0i.org/10.1007/978-94$\underline{6209-143-6}$

Desta, I. (2017). Penerapan Pendekatan Science, Technology, Engineering, Arts, and Mathematics (STEAM) dalam Upaya Mengembangkan Kemampuan Berpikir Kreatif Peserta Didik melalui Project Based Learning. Skripsi. UIN Jakarta.
Fatimah, C. (2017). Penerapan Pendekatan STEAM (Science, Technology, Engineering, Arts, and Mathematics) dalam Upaya Mengembangjan Keterampilan Abad 21 Menggunakan Project Based Learning. Skripsi. UIN Jakarta.

Hanafi. (2017). Konsep Penelitian R\&D dalam Bidang Pendidikan. Jurnal Kajian Keislaman. 4(2), Accessed from http://jurnal.uinbanten.ac.id/index.php/sa intifikasilamica/article/view/1204

Hu, W., Adey, P. (2002). A Scientific Creativity Test for Secondary School Students. International Journal of Science Education, 389-403.

Ismayani, A. (2016). Pengaruh Penerapan STEM Project Based Learning terhadap Kreativitas Matematis Siswa SMK. Indonesia Digital Journal of Mathematics and Education, 3(4), 264-272.

Miller, A. (2017). PBL and STEAM Education: A Natural Fit. https://www.edutopia.org/blog. Diakses pada tanggal 1 Februari 2019

Reza, A.M. (2017). Penerapan Pendekatan Pembelajaran Science, Technology, Engineering, Arts, and Mathematics (STEAM) dalam Upaya Mengembangkan Soft Skills Peserta Didik Menggunakan Project Based Learning. Thesis. Universitas Negeri Jakarta. Spiko, D., N. Jalal, P.T. Cerrato \& M. Marcello. (2017). Emerging Design: Transforming the STEAM Learning Lanscape with the Support of Digital Technologies. Interaction Design and Architecture(s) Journal, 9(34), 5-6.

Trilling, Bernie and Fadel, Charles. (2009). 21st Century Skills: Learning for Life in Our Times, John Wiley \& Sons, 978-0-47-055362-6. 